
\title{
Projection of Fractured Parenthood in Toni Morrison's The Bluest Eye and Song of Solomon
}

\author{
Srikumari Panda
}

Ph. D Scholar, F. M. University, Balasore, Odisha

\begin{abstract}
This article studies and records the failed and fractured parenthood in Toni Morrison's fiction who are the victims of slavery and its aftermaths. Morrison in her novels like The Bluest Eye, Song of Solomon, Beloved, Sula and Jazz has exposed a true account of the African Americans' difficulties, trial and failure to maintain a solid familial and communal relationship, devastated by the dreadful atrocities of slavery. Sandwiched between dual nationalism: African and American, dual identity: African American, actually they neither exist as Africans nor as Americans in the troubled land of America. As an African American author, editor, educationist, Toni Morrison is very particular about dealing with the complexity of this dual identity in relation to its historical and social context. In a comparative and analytical method, this article presents different dimensions of a slave's personality in his real life situations. Being devoid of true identity and being reduced to the state of non-human entity, s/he fails to play the role of a wife, husband, mother or father in the family as well as in community. Sometimes the slave becomes a beast and sometimes a flying African due to the crisis of identity. Children become the victims of these victimized parents for which they either die a premature death or goes mad as portrayed in Morrison's fiction.
\end{abstract}

Keywords: Slavery, Trauma, Identity, ethnicity, African- American, persecution

\section{Introduction}

The sociologically and sentimentally significant issues of slavery, racism and sexism have always been the critical points for the subjugation of the black Africans in white America.

In an alien land, the issue of identity formation has always been a complex and not always a successful process for the African Americans, which has been shadowed under the institution of slavery. Morrison discusses the problem of shaping and reshaping of identity with reference to relationship, ownership, mother-daughter dependency, individual, community, and above all to the origins of African American history. She reconstructs the reasons of the lost identities of the faceless, nameless non-entities who were the subjects and objects of persecution, objectification and commoditization in her fiction. Their lack of identity and authenticity take the form of fear, frustration, hatred, jealousness and violence and is transferred to the family life. As a result, these victimized slave parents become the victimizers for their own children and make them victims of their fractured parenthood.

Through her characters Toni Morrison seeks an understanding of the formation of identity, its main determinants and consequences. In her novels, the void between the rich and the poor, the gulf between blacks and whites and the drift between man and woman is clearly represented. Her debut novel The Bluest Eye portrays the complexity of colonial relations and identity difference between blacks and whites, freeman and slave, patrician and plebeian, lord and serf, guild master and journeyman, in a word, oppressor and oppressed which destroys the parentchild relationship in particular. This novel depicts the struggling story of Pecola Breedlove and Claudia Macteers, two ordinary African American girls with social forces of racism and poverty. These black families are the immigrants from the South, living in Lorain, Ohio. This novel explores their happy and painful experiences in growing up and the formal and informal education of their children that leads them to self understanding. The Breedloves profoundly lack self esteem, love and happiness within the family and ironically enough they hate each other.

Pauline Breedlove, Pecola's black mother who is lame in one foot, believes that she is ugly and the children she bears are also ugly and black. In order to attain the white beauty standards and to cope with the identity crisis, she spends most of her time at the movies, from which she absorbs racist ideas of female beauty and starts to dislike her own appearance. The theatre fills her mind with the images of the white silver screen idols and encourages her to imitate the stars of the 1930s. She also disliked and despised her newborn daughter Pecola as she was also ugly and black like her. Her daughter looks to her like "a cross between a puppy and a dying man" (97-98). She even did not support Pecola emotionally during her initiation into womanhood by attaining puberty which is one of the most important events in the life of a girl. Poverty, economic deprivation, separation from the agrarian society and nature, exposure to the tempting but corroding values of the majority culture, and the bitterness of racial hatred forced her to build a pseudo identity as Mrs. Breedlove by doing domestic work for a white family and by creating an alternative fantasy family as she failed to make her own. Emotionally abandoning her own family, she enjoys the status of the servant of the white family. Rejecting the sentiment and psychology of Pecola, she displays loyalties with the white children. Instead of building a unique identity of herself by loving her own image, own family and community, she takes pride in being loyal and obedient to the white family. In the Fisher household, her artistic temperament could be channeled into creativity as there was no scope for dream fulfillment at her own home. Her failure as a mother attains the extreme end when she refuses to believe Pecola's molestation by her father. Rather she slapped Pecola and physically ill treated her which examples a victim turning victimizer. In this vicious circle, Pecola longs for blue eyes,

Volume 6 Issue 12, December 2017 


\section{International Journal of Science and Research (IJSR) \\ ISSN (Online): 2319-7064}

Index Copernicus Value (2016): 79.57 | Impact Factor (2015): 6.391

a symbol of white beauty, which she believes would make her beautiful, acceptable and admirable.

Pauline, faces the identity crisis in the form of alienation. She loses both her family and the Southern black community when she moves North in search of economic opportunity with Cholly and her children. Lack of opportunity to artistic expression of creative energy is one of the most important factors for black women's failure in their quest for self. Pauline Breedlove's artistic temperament faces obstacles with the migration. She longs for the rainbow colors and smells of her native rural background of Alabama hills. She misses its 'June buggs': “... the cool yellowish lemonade with its seeds floating her mother made" (90) and longs for the natural beauty in the concrete jungle of the city.

Cholly, Pecola's father has been totally destroyed and frustrated by racist humiliation, poverty and the mockery of his powerlessness which has left him drunken and irresponsible family head. The most dominating feature of his character is his impulsive nature. Morrison describes, "He roamed about freely, guided by nothing but what that moment dictated him" (126). He goes to the extent of beating his wife like a beast and finally rapes his own daughter, which serves as an illustration of the classic response of black man's powerlessness towards their women. W.E.B. Dubois describes that the victimized black man transforms his sense of powerlessness, impotence, castration and dehumanization to black woman and victimize her who is subordinate to him.

Pecola Breedlove is negatively influenced by these idealized notions of white superiority that pushes her into an unfortunate type of lack of self. Her adolescent mind encounters constant quarrel between her father and mother at home, and fails to get the love and affection from them within the family. She finds no scope for relaxation within her friend circle as she was also the child victim of racism and sexism within the community, where she feels an imposed invisibility of her existence and reduced to a state of object. She is verbally attacked by her light skinned friend and made to be ashamed of for everything that she does and even thrown out of the home of her friends. The misfortune of Pecola does not end here. She is raped and violated by her drunken father and emotionally abandoned by her mother which leads to the lost of her existence permanently. In the book Toni Morrison, Wilfred D. Samuels and Clenora Hudson Weems describe:

Equally significant is the physical violence done to the black child by parents who are themselves confused about their identity, as it is the case with the Breedloves. In the end, when Cholly rapes her daughter, it is a physical manifestation of the social, psychological and personal violence that, together with his wife, he has put upon Pecola. Mrs. Breedlove blames Pecola for the rape and puts her out (14).

After the rape, Pecola's appearance was filled with utmost disgust. Again Morrison elaborately explains her madness in these words:
The damage done was immense and she spent her days, walking up and down her head jerking to the beat of a drummer so distant only she could hear. Elbows bent, hands on shoulders, she flailed her arms like a bird in an eternal, grotesquely futile effort to fly. Beating the air, a winged but grounded bird intent on the blue void it could not reachcould not even see- but which filled the valleys of the mind (204).

Here Pecola is described as a winged but grounded bird whose broken self, after incestuous rape, prevents her flight into wholeness. In her appreciation of physical beauty, she is an extension of her mother's personality as girls identify themselves with their mothers. Her quest for self respect through achieving blue eyes culminates in madness and ironically named, the Breedloves do not give her a life of love: familial, romantic or personal. Her quest for blue eyes is described thus: "Each night, without fail, she prayed for blue eyes. Fervently, for a year she had prayed. Although somewhat discouraged, she was not without hope. To have something as wonderful as that happen would take a long, long time" (346). She was desperately in need to have the blue eyes, and she feels that as she has no blue eyes, she suffers from self-scorn that creates a kind of scar on her heart.

Pecola is on a quest for her identity, which cannot be separated from the love and affection for which she longs for. Her victimized parents failed to teach her any measures of self-protection; rather they have simply transmitted their own sense of worthlessness, their regular fights which resulted in the damage of the psychic wholeness of Pecola and Sammy, her brother. It is the family atmosphere which also makes Sammy run away from it twenty seven times by the time he is fourteen years old. But, Pecola, being a girl, has no scope to escape from this situation. Unable to escape due to the fear of her parents, she keeps on tolerating these sufferings. Being raped by her own father, being a mother at the age of twelve and delivering a still-born child are the additional trauma which caused her mental breakdown and she retires to the state of mind as madness. She fights to find herself in infertile soil and wants to come out of a life of sterility. But unfortunately, like the marigolds planted that year, Pecola never grew. Self, after incestuous rape, prevents her flight into wholeness.

In Song of Solomon, the story and reality of identity crisis continues. Hagar, Pilate's grand daughter who is madly in love with Milkman, desperately attempts to transform herself into a beautiful and lovable woman with the help of cosmetics, when Milkman rejects her after using her for a long time. Like Pecola she is unable to evaluate her own worth and value although she is quite mature and elder than Pecola. This self-negation and hatred is followed by madness in Pecola's case and death in Hagar's case. Song of Solomon depicts the desperate journey of Milkman to build an identity of his own and to understand his roots, base and ancestry. According to Dorothy $\mathrm{H}$. Lee, he passionately travels from innocence to awareness, from ignorance of origins, heritage, identity and communal responsibility to knowledge and acceptance. 


\section{International Journal of Science and Research (IJSR) \\ ISSN (Online): 2319-7064}

Index Copernicus Value (2016): 79.57 | Impact Factor (2015): 6.391

Because of his apathy, indifference and egoistic attitude towards money and women like his father, he grows insensitive towards everybody around him. He is easily biased in such a way that when he listens to his father, he hates his mother and when he sympathizes his mother, hurts his father. Within this circle and circumstances, he could not be able to understand that he was gradually drifting away from his family. As he has no sense of belonging to his family, their fears, their woes and their feelings do not make any impression on his mind. He feels that "His whole family was a bunch of crazies" (76). In Song of Solomon, Toni Morrison presents a fractured parents-son, brother-sister and communal relationship through the characters of Macon Dead II, Ruth, Milkman Dead, their son and daughters. Ruth, Milkman's mother is portrayed as a female character that faces identity crisis in form of domestic violence, oppression and suppression. Macon Dead II marries her with a purpose, who is the only daughter of the only black doctor of the town. Through this marriage, he acquires wealth, status and power, and proves to be a hard hearted master, husband and father. His patriarchal values has reduced Ruth into a lifeless shadow and rendered his two daughters' lives useless. To validate her identity in a sterile marriage, she visits her father's grave at night. What she does not get from her living husband gets from her dead father, which verifies Morrison's effort to demonstrate the consequences of inauthentic existence. Ruth verbalizes her awareness of her lack of personal identity when she describes herself to her son:

I was pressed small. I lived in a great big house that pressed me into a small package. I had no friends, only schoolmates who wanted to touch my dress and my white silk stockings. But I didn't think I'd ever need a friend because I had him [her father]. I was small, but he was big. The only person who ever really cared whether I lived or died... he cared... and there was, and is no one else in the world ever did (124).

She accepts herself "a small woman" and "pressed small" because she does not know how to fight for the selfhood like a rebel as does Sula. She remains empty, isolated, inauthentic and frustrated as a result of the death of her beloved father, dominance of her abusive husband and lack of feelings of her son. Because she has no independent self on which she can stand. But still, she is strong enough not to go inane like Pecola, or die like Sula.

On the other hand, Macon Dead II was attracted by the materialistic culture of the North and to some extent he could survive better by accumulating wealth and power status though he failed in achieving the love and warmth from his family and community. His individualistic and narcissistic attitude made him devoid of family values and humanity. Macon Dead II teaches Milkman,” Let me tell you right now the one important thing you'll ever need to know: own things. And let things you own other things. Then you will own your self and other people too" (55). This teaching of the father made Milkman a diehard person as Harve Minakawa describes in his article "The Motif of Sweetness in Toni Morrison's Song of Solomon": ... Milkman is simply a northerner with a white mind" (52).
Milkman is wrongly directed according to the wish of his father until he becomes thirty and becomes aware of the thing that he is getting bored with everything and everyone. Morrison describes: "Boredom which had begun as a mild infection, now took him over completely. No activity seemed worth the doing. No conversation worth having" (90). Again she says," He was bored, everybody bored him. The city was boring. The racial problems that consumed Guitar were the most boring of all" (107). The boredom and lack of interest is the primary manifestation of the self's alienation with family, community as well as with itself. In a peculiar way Milkman started to feel that others are using him for their own purposes. He feels as described by the author: "Somehow everybody was using him for something...making him the subject of their dreams of wealth, or love, or martyrdom" (165). This feeling makes him frustrated, disappointed and suffocated. In Sula lack of a particular art form made her dangerous. Her inner strength and stability could not find a proper way to be manifested, for which she was destroyed. Here, up to the age thirty Milkman remained a Papa's boy without experimenting an initiative on his own part. He lacks any model to which he can follow, or a source of inspiration for him to copy. Because within the family, he could find his depressed sisters and suppressed mother and outside the family, Guitar, the revolutionary friend and guide who were of no use in inculcating any positive and constructive approach to life for him, as they were the victims of hatred, domestic violence, self destruction and negation of life.

In this juncture, his father motivates Milkman to steal from Pilate, his father's sister, their family gold which she hid in the South. "... get it and you can have half of it; go wherever you want. Get it. For both of us. Please get it, son. Get the gold" (173). Initially, as per the advice of his father, Milkman put his effort to rob Pilate of the material wealth. But his introduction with Pilate changed her life from a sterile to productive one. Milkman finds a sack of bones instead of gold as told by his father. Later he discovered that the bones belonged to his ancestors. As a true culture bearer Pilate remains a proper spiritual guide for her nephew without whom he could not have supervised towards the correct way of identity building: "Now he knew why he loved her so. Without ever leaving the ground, she could fly" (336). She is connected to her community and transcends it through her distinct identity. "Milkman's journey to Danville and Shalimar places him in the presence of his past. It marks the point of his separation from the false community of the Deads and begins the rite of passage that will result in his incorporation into his ancestral community" (65). At the beginning of the journey, Milkman is more or less a "white Negro, but later he is well merged into his own race among its members. In Danville, Pennsylvania, he learns the story of his family's past. For the first time in his life he basked in the sunshine of his ancestral glory when he discovers love in family and community. He abandons his sense of class superiority and wishes to immerse himself in that black race which memorizes and glorifies his ancestry and his family roots. It's just because of Pilate, that Milkman could be able to regain his self confidence and to retrieve his lost identity. 


\section{International Journal of Science and Research (IJSR) \\ ISSN (Online): 2319-7064}

Index Copernicus Value (2016): 79.57 | Impact Factor (2015): 6.391

In this book journey or fleeing away from the plight of slavery plays an important theme which disturbs and devastates the family life even for generations. Symbolically, 'flying' away from something or flying toward a goal signifies black man's aspiration to seek freedom to escape death, or to pursue a better, more liberating life for themselves and their families in particular and man's universal quest for freedom in general. The legend of the flying African is a recurrent motif in African American folklore and it has been originated in the desire of the slave to fly away from his miserable life. The epigraph of this novel says: "The fathers may soar, / And the children may know their names"; which indicates that the fathers who are integral to the survival of black families, leave behind their children and wives. They need to be physically and emotionally present in their children's lives. But paradoxically, in the contemporary American society, black fathers are often absent; leaving the demanding job of raising children to the mothers, as they are often forced to abandon this role due to societal pressures. This mobility of American culture symbolizes how the Black Africans are cut off from their past and rootedness by being estranged from their families. And the sequence of ancestry, familial network, life and heritage breaks in all aspects; political, economic and social. Thus the concept of 'flight' alludes to the alarming statistics concerning the poor status of black male and the resulting threat to the survival of the black family. The children of the flying Africans suffer discontinuity of every kind, as they lose their homes, a sense of their fathers, a sane, stable and beloved mother, and their racial roots, kiths and kins. The flying with no promise to come back shortly may costs the men maturation, individualizations, connections and a sense of self, but to restart the life in case of children without the roof of a father figure is next to difficult. They are left with the valuable message that they are the self-reliant, autonomous adult children now. Flying away from the whole problem is an easier answer, which poses a permanent question mark about the future life of the children, which is ambiguously dark.

Still, Morrison sympathetically depicts these men as strong and adventures responding to a powerful urge to move on and be free. Slavery makes their existence burdensome to such an extent that they find no ways except flying away elsewhere to escape it leaving all the responsibilities on their wives. Their children must ultimately pay the price for their fathers' absence, but absentee fathers leave a strong legacy for their children: As long as children "know their names" that is, know who their fathers, their ancestors are- they can cope with the habit and courage of being raised without a father. In this fiction, four generations of a black family revolve around the very act of flight and in each generation, the father figure is either physically or emotionally absent. And it is the children who remember it, sing about it, mythologize it, and make a part of their family history, as their loss is irreparable. Their song certainly expresses the memory of their father's hope for deliverance from the sorrows of this world and their courage to do this.

\section{Conclusion}

This is how both the novels project the injured parenthood due to the troubled identity of the protagonists for being black. Race and color, slavery and its aftermaths have ruined the black life from childhood to adulthood. Escapism from this ill-managed society is but a dream for them. Family is the primary institution where the child's growth and development begins. According to Nancy Chodorow's The Reproduction of Mothering and Family Structure and Feminine Personality, girls identify themselves with their mothers with the empathetic understanding of each other's needs and experiences. But the mothers in almost all novels of Toni Morrison demonstrate a troubled motherhood under the shadow of slavery. The responsibility of a black mother to teach her children to be proud of who they are is often shadowed by the memory of the subjugation and humiliation faced by her due to racism, slavery and poverty. Generally, people are strongly influenced by the way others treat them. Family, friendship, love, care, affection and understanding shape one's personality. But the children in Morrison's novels are not that lucky to attain these things and hence they lead strange childhoods and strange coping strategies.

\section{Acknowledgement}

The author of this article is thankful to the Osmania University Central Library, Hyderabad for the extended support to collect the related materials in a very smooth way. The assistance provided by F. M. University, Balasore and Ravenshaw University, Cuttack during the completion of this work is greatly acknowledged.

\section{References}

[1] Chodorow, Nancy. The Reproduction of MotheringPsychoanalysis and the Sociology of Gender. Berkeley: University of California Press, 1978. Print

[2] Kolchin, Peter. American Slavery: 1619-1877. New York: Hill and Wang Paperbok, 1994. Print.

[3] Lee, Dorothy H. "The Quest for Self: Triumphs and Failure in the Works of Toni Morrison". The Black Women Writers: A Critical Evaluation (1950-1980), ed. Meri Evans. New York: Double Day Publishing Company, 1983. P-346.

[4] Minakawa, Harve. "The Motif of Sweetness in Toni Morrison's Song of Solomon”.Kyushu America Literature. 26 October. 1985. (47-56).

[5] Mobley, M.S. Toni Morrison: Critical Perspectives of Past and Present. New York: Amistad, 1993.

[6] Morrison, Toni. Song of Solomon. United States: Alfred A. Knopf, 1977. Print.

[7] ---. The Bluest Eye. London: Vintage, 1999. Print.

[8] Rosenberg, Ruth. "Seeds in Hard Ground: Black Girlhood in The Bluest Eye". Black American Literature Forum. Vol. 21, No. 4 (winter, 1987), pp. 435-445.

[9] Samuels, Wilfred D. and Clenora Hudson-Weems. Toni Morrison. Boston: Twayne Publishers, 1990. Print. 